\title{
FAILURE OF DEVICES USED FOR CLOSURE OF ATRIAL SEPTAL DEFECTS: MECHANISMS AND MANAGEMENT
}

Surendra K. Agarwal, MCh

Probal K. Ghosh, MCh, FRCSE

Pramod K. Mittal, MCh

\begin{abstract}
Various devices for transcatheter ASD closure are undergoing clinical trials. Each new device claims advantages in terms of safety and efficacy over earlier devices. We report three cases in which a new investigational device-the Das angel wings-failed. Emergency operations were necessary for device retrieval and defect closure. The possible mechanisms of the event and the options in management are discussed with a review of literature on all devices. (J Thorac Cardiovasc Surg 1996;112:21-6)
\end{abstract}

T ranscatheter closure of atrial septal defects (ASDs) was introduced two decades ago. ${ }^{1}$ Four devices have been described so far. The devices have been associated with occasional failures necessitating their retrieval by transcatheter or surgical means and occasional complications such as device embolization and transient ischemic attacks.

In 1993 Das and colleagues ${ }^{2}$ introduced a new device intended to decrease rates of failures and complications, and they used it successfully in a dog model. Recently an international clinical trial with this device was started. After a hospital ethics committee review was conducted for a monitored trial, six patients underwent implantation of the Das angel wings device at our center. The following criteria were used for patient selection: (1) a fossa ovalis ASD less than $20 \mathrm{~mm}$ as measured on echocardiography; (2) a left-to-right shunt of 1.5:1 or more in the absence of severe pulmonary arterial hypertension; and (3) absence of other intracardiac defects necessitating surgical correction. Informed consent was obtained from each patient. In three of these patients, the device was deployed successfully. Two patients made an uneventful recovery and were discharged 48 hours after the procedure. In the third patient transient

From the Department of Cardiovascular and Thoracic Surgery, Sanjay Gandhi Postgraduate Institute of Medical Sciences, Lucknow, India.

Received for publication Sept. 11, 1995; revisions requested Nov. 6, 1995; revisions received Dec. 11, 1995; accepted for publication Dec. 13, 1995.

Address for reprints: Probal K. Ghosh, MCh, FRCSE, Chairman, Department of Cardiovascular and Thoracic Surgery, Sanjay Gandhi Postgraduate Institute of Medical Sciences, Raebareli Rd., Lucknow, 226 014, India.

Copyright (C 1996 by Mosby-Year Book, Inc.

$0022-5223 / 96 \$ 5.00+0 \quad \mathbf{1 2 / 1 / 7 1 1 7 0}$ complete heart block developed but resolved after 72 hours, and the patient was discharged after 1 week. No residual shunt was detected at immediate or follow-up echocardiography. All three patients are doing well at 3 to 6 months' follow-up, and none has had infective endocarditis.

We shall now describe three patients with acute failure of this device who required emergency surgical management. This is the first report of surgical management after failure of the angel wings device used for ASD closure.

\section{Case reports}

CASE 1. A 26-year-old woman with no symptoms was confirmed to have secundum ASD on echocardiography. Transvenous closure was attempted on February 26, 1995. A long $14 \mathrm{~F}$ sheath shaped to enter the left atrium was placed in the right femoral vein and a $5 \mathrm{~F}$ sheath was placed in the femoral artery for pressure measurements. Under fluoroscopic control, a balloon was used to measure the stretched diameter of the ASD. A $30 \mathrm{~mm}$ Das device was implanted to occlude the ASD. After the device was released, it slipped back into the right atrium. It was snared and retrieved up to the right common iliac vein but could be advanced no further. The device was left in this position. A second attempt was made from the left femoral vein with a $35 \mathrm{~mm}$ device. This too slipped into the right atrium. At an emergency operation, the device was easily identified and removed after the right atrium was opened. The ASD was closed by direct sutures. The patient was weaned uneventfully from cardiopulmonary bypass. Through a vertical incision in the right groin, the other device was removed from the right common iliac vein. The vein was then directly repaired. The patient recovered without complications and was discharged on the sixth postoperative day.

CASE 2. A 23-year-old woman with secundum ASD underwent transcatheter closure on April 25, 1995. A 40 $\mathrm{mm}$ Das device was inserted via the right femoral vein. The device was successfully implanted, but within seconds of implantation it slipped into the left atrium. It could not be retrieved by being snared. The woman was in hemo- 
Table I. Clinical details of cases

\begin{tabular}{|c|c|c|c|}
\hline & Case 1 & Case 2 & Case 3 \\
\hline Weight $(\mathrm{kg})$ & 43 & 40 & 50 \\
\hline RA size (mm) & 50 & 40 & 49 \\
\hline LA size $(\mathrm{mm})$ & 40 & 31 & 40 \\
\hline $\begin{array}{l}\text { Stretched ASD } \\
\text { diameter }(\mathrm{mm})\end{array}$ & 5 to 18 & 16 to 18 & 16 to 22 \\
\hline PAP $\mathrm{s} / \mathrm{d} / \mathrm{m}$ & $44 / 16 / 24$ & $15 / 0 / 6$ & $32 / 6 / 16$ \\
\hline $\mathrm{Qp} / \mathrm{Qs}$ & $8.4: 1$ & $2.07: 1$ & $3.48: 1$ \\
\hline PVRI & 0.72 & 1.03 & 1.11 \\
\hline Device size $(\mathrm{mm})$ & 30,35 & 40 & 35 \\
\hline Femoral sheath & $14 \mathrm{~F}$ & $14 \mathrm{~F}$ & $14 \mathrm{~F}$ \\
\hline Complication & $\begin{array}{l}\text { First device slipped into RA and } \\
\text { was extracted from RCIV; } \\
\text { second slipped into RA }\end{array}$ & Slipped into LA & Slipped into LA \\
\hline Operation & $\begin{array}{l}1.5 \times 1.0 \mathrm{~cm} \text { FO ASD; } \\
\text { second device in RA; } \\
\text { first device in RCIV } \\
\text { removed by venotomy }\end{array}$ & $\begin{array}{l}1.2 \times 0.7 \mathrm{~cm} \text { ASD; device in LA; } \\
\text { one flange across MV orifice }\end{array}$ & $2.6 \times 1.2 \mathrm{~cm}$ ASD; device in LA \\
\hline
\end{tabular}

$R A$, Right atrium; $L A$, left atrium; $A S D$, atrial septal defect; $P A P$, pulmonary arterial pressure; $s$ systolic; $d$, diastolic; $m$, mean; $Q P$, pulmonary blood flow; $Q s$, systemic blood flow; $P V R$, pulmonary vasculature resistance (indexed); $R C I V$, right common iliac vein; $F O$, fossa ovalis; $M V$, mitral valve.

dynamically stable condition when taken for an emergency operation to retrieve the device and close the defect. The device was seen in the left atrium through a 2 $\mathrm{cm}$ ASD with a nonfibrous inferior margin. The device was retrieved through the ASD and the defect was closed directly. The patient made an uneventful recovery and was discharged. She remains well at 2 months' follow-up.

CASE 3. A 30-year-old woman with asymptomatic secundum ASD elected to undergo device closure of the ASD on April 26, 1995. A $35 \mathrm{~mm}$ Das device was used for implantation, but it could not be properly released. On a second attempt, after release of the second disc, it slipped into the left atrium. The patient's condition remained hemodynamically stable. At emergency operation the ASD, seen through a right atriotomy, was $1.6 \mathrm{~cm}$ in diameter with good margins. The device was easily identified lying in the left atrium and was removed through the defect. The ASD was closed primarily. The woman recovered without complications and was discharged on the seventh postoperative day. She is free of symptoms and doing well at 2 months' follow-up. The details of the echocardiographic, catheterization, and surgical findings of all three patients are given in Table I.

The failure in these three cases may be ascribed to technical reasons and lack of operator expertise. In one case the fact that the device was too large led to difficulty in manipulation and proper positioning of the left atrial disc. In the other two the device slipped back after deployment. The operations were necessary because the design of the device made transcatheter retrieval difficult.

Although the use of an ASD closure device was new for this institution, the principal investigators (who performed the procedures) are widely experienced in invasive procedures and have a high success rate with transcatheter ductus closure in this institution.

\section{Discussion}

ASD is the fifth most common congenital cardiac anomaly and occurs with a frequency of 3.2/10,000 live births. ${ }^{3}$ It is being detected with even greater frequency because of the more widespread use of echocardiography. Surgical management of ASDs is safe and simple but is associated with occasional mortality, morbidity, and high expenses. Patent foramen ovale, with a prevalence at autopsy of $27 \%$ to $35 \%,{ }^{4}$ may cause paradoxic embolism ${ }^{5}$ and necessitate surgical closure to prevent this complication. Interatrial communication after a fenestrated Fontan procedure may also indicate closure of the defect at a later date. With a view to decreasing the cost, hospital stay, and surgical complications, transvenous closure of these defects was introduced.

After the first report of such a device by King and associates $^{1}$ in 1976, several such devices were developed. Two devices (Lock clamshell ${ }^{6}$ and Sideris buttoned device ${ }^{7}$ ) have undergone clinical trials. Table II describes various devices and their main features. Table III is a brief review of the literature concerning use of these devices in various subgroups. All devices have been associated with instances of failure and complications (Table III). The clamshell device has been withdrawn and is undergoing further modifications.

There are several reasons for acute failure of these devices. The most important mechanism is poor case selection (i.e., too large a defect) or device 
Table II. Types of ASD closure devices

\begin{tabular}{|c|c|c|c|c|}
\hline Device name & Reference & Features & $\begin{array}{l}\text { Minimum size } \\
\text { of Femoral } \\
\text { sheath required } \\
\text { for deployment }\end{array}$ & $\begin{array}{l}\text { Current } \\
\text { status }\end{array}$ \\
\hline King umbrella & King ef al. ${ }^{1}(1974)$ & $\begin{array}{l}\text { Two Dacron discs with } \\
\text { stainless steel skeletons } \\
\text { resembling umbrellas; complex } \\
\text { delivery mechanism; bulky }\end{array}$ & $23 \mathrm{~F}$ & Currently not used \\
\hline Rashkind umbrella & Rashkind $^{8}$ (1983) & $\begin{array}{l}\text { Single disc occluder of } \\
\text { polyurethane foam; three of } \\
\text { six wires comprising its } \\
\text { umbrella-like skeletons end } \\
\text { in small sharp hooks that } \\
\text { imbed into atrial septum; } \\
\text { cannot be retrieved }\end{array}$ & $16 \mathrm{~F}$ & Currently not used \\
\hline Bard clamshell & Lock et al. $^{6}$ (1989) & $\begin{array}{l}\text { Double disc composed of woven } \\
\text { Dacron fabric over a complex } \\
\text { multiple-jointed wire skeleton } \\
\text { with a metal knuckle extending } \\
\text { from the center to attach } \\
\text { the device to the delivery system }\end{array}$ & $11 \mathrm{~F}$ & Clinical trials underway \\
\hline $\begin{array}{l}\text { Sideris buttoned } \\
\text { occluder }\end{array}$ & $\begin{array}{l}\text { Sideris et al. } \\
\quad(1990)\end{array}$ & $\begin{array}{l}\text { Two discs of polyurethane foam } \\
\text { over a metal skeleton of Teflon-coated } \\
\text { stainless steel wire-guide material, } \\
\text { inserted separately and } \\
\text { sequentially, positioned on each } \\
\text { side of the atrial septum and then } \\
\text { "buttoned" together; the button is } \\
\text { made by a short loop of nylon } \\
\text { suture attached to the } \\
\text { skeleton center that contains a } \\
\text { knot with a radiopaque marker }\end{array}$ & $11 \mathrm{~F}$ & Clinical trials underway \\
\hline Das angel wing & Das ef al. ${ }^{2}$ (1993) & $\begin{array}{l}\text { Double disc of polyester with } \\
\text { nitinol skeleton, which forms a } \\
\text { square at the periphery of } \\
\text { each disc; no central wire skeleton; } \\
\text { two discs are sewn together in a } \\
\text { central oval area; knuckle } \\
\text { and eye release system on } \\
\text { one corner of right-sided disc }\end{array}$ & $13 \mathrm{~F}$ & $\begin{array}{l}\text { Investigational (study } \\
\text { patients are } \\
\text { part of first } \\
\text { clinical trial) }\end{array}$ \\
\hline
\end{tabular}

selection (low ratio of device to defect). Rao and associates ${ }^{19}$ have described protocols for the selection of patients and devices. Rosenfeld and cowork$\mathrm{ers}^{17}$ described echocardiographic predictors of candidacy for successful transcatheter closure of these defects. They found that the success rate was only 59\% in ASDs larger than $13 \mathrm{~mm}$ as compared with $100 \%$ in defects smaller than $13 \mathrm{~mm}$. The other suggested mechanisms of acute failure are (1) operator-related failure resulting from inadequate experience (learning curve), (2) inaccurate deployment, (3) inadequate defect rim to hold the device, (4) tearing of the interatrial septum especially at the lower rim of the ASD owing to catheter and device manipulations, ${ }^{20}$ and (5) the failure to button the
Sideris buttoned occluder or unbuttoning of this occluder. ${ }^{19}$ Chronic/late failure has been reported to result from unbuttoning and fracture of the wire framework of the Sideris device. ${ }^{21}$ Various complications may occur. A part of the device or the whole device may embolize to the right or left atrium, main pulmonary artery, or even to other parts of the vascular tree on both the right and left sides of the circulation. ${ }^{10-12,19,22}$ Thromboembolic episodes may occur as a result of poor endothelialization of these devices, necessitating long-term use of anticoagulants or even surgical removal of the device. ${ }^{14}$ Other reports have described atrial perforation and hemopericardium. ${ }^{19}$ Atrial arrhythmia and atrioventricular valve regurgitation may be caused by the 
Table III. Review of $A S D$ closure device failures and complications

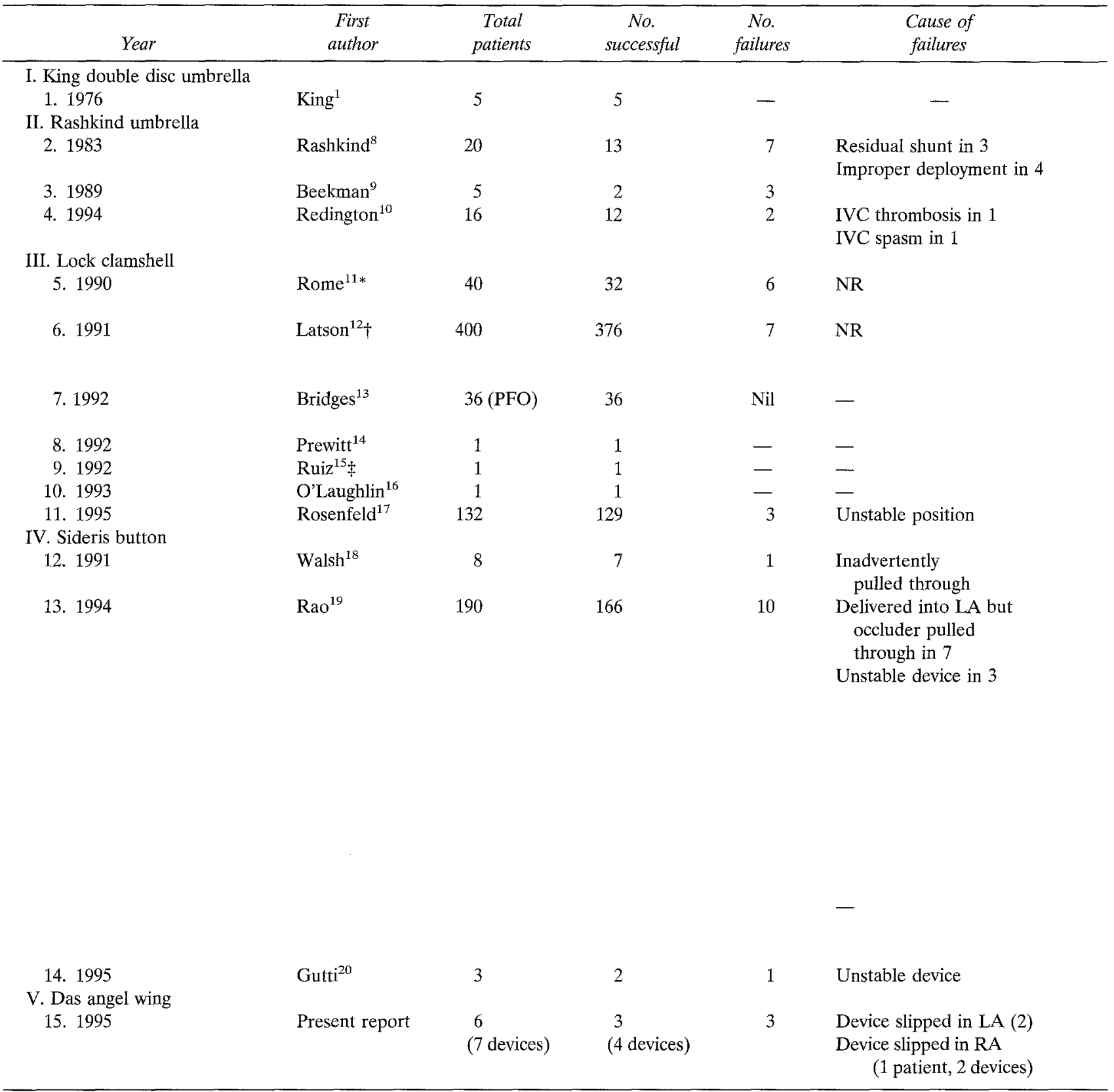

PFO, Patent foramen ovale; $I V C$, Inferior vena cava; $N R$, not reported; $L A$, left atrium; $R A$, right atrium; $M P A$, main pulmonary artery; $T L A$, transient ischemic attack; $A S D$, atrial septal defect; $M R$, mitral regurgitation; $T R$, tricuspid regurgitation; $R C I V$, right common iliac vein.

*Includes 12 Rashkind and 3 modified Rashkind devices.

tIncluded some cases reported in references 5, 7, 11, and 12.

$\ddagger$ As rescue procedure with MVBD and AVBD.

device impinging on the atrial tissue or atrioventricular valves. Also, a high rate of residual shunt has been reported with the use of these devices. In the cumulative global experience (with all types of devices) in nearly 900 patients, the device failure rate is about $5 \%$ and the complication rate is $9 \%$.
Surgical intervention has already been performed in $4 \%$ for complications and failure, and another $4 \%$ will undergo operations for device failure.

Das and associates ${ }^{2}$ developed their new device with the intention of reducing these failures and complications. The nitinol wire framework at the 
Management of failures

\section{- \\ Surgery in 5 (emergency in 4)}

NR

NR

Removed before release

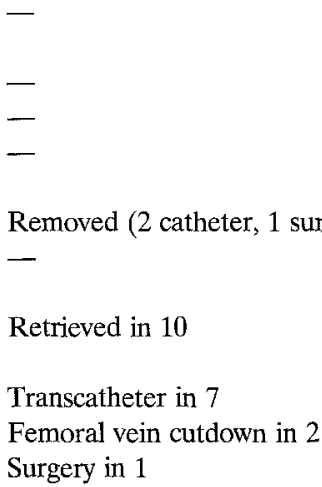

Surgery in 1
Unstable device in 1

Embolization to MPA in 1

Cath-related cerebral death in 1

Embolization to common iliacs 2

Embolization in 17 (3 systemic)

Vessel damage in 2

Air embolism in 6

Brachial plexus injury in 1

TIA in 4

$30 \%$ wire fracture at hinge; TIA after 6 mo

$-$

Unbuttoning and embolism in 13

Whole device in 1

Atrial perforations in 2

Residual shunt in 2

Transient atrial arrhythmias in 1

Trivial MR in 3

Trivial TR in 2

Few cases of right-sided air bubble

Wire distortion at 6 month in 2

Embolization to axillary artery in 1

Paradoxic embolism (TIA) in 1

Tear of inferior rim of ASD

found at surgery

Transient heart block in 1

3 (1 trivial, 2 clinical)

3

Surgery in 2

Surgery in 2

NR

NR

Surgery (device removal)

-

$-$

Embolism, catheter removal in 4

Surgery in 10

Surgery in 3

Removal of wire, device left behind in 2

Surgery in 1

Surgery

NR

Nil

Surgery in 3

One device removed through

RCIV by cath, then venotomy

periphery of the Dacron fabric disc serves to keep the edges of the discs in close apposition to the atrial septum, and the large central connection between the two discs is supposed to reduce the tendency of the device to move along the atrial septum, potentially reducing the device/defect ratio. A special delivery system was designed to permit precise and reliable deployment of the device. The device has been successfully used in animal models, and clinical investigations were started in 1995.
The management of failures and complications usually involves snaring and transcatheter retrieval of the device with later surgical closure of the defect. However, if the device cannot be retrieved or causes complications (e.g., device embolization or atrial perforation) posing an emergency, prompt surgical management is required. In some instances in which the device is not obstructing any cardiac valve or vessel lumen, with a small and self-limiting atrial leak, and a stable hemodynamic state, the patients 
may be regularly followed up until elective surgical closure of the defects.

Although devices are useful alternatives to surgical closure in selected cases, they are not without attendant failures and complications. The state-ofthe-art devices have not yet proven to be superior to presently available devices. Thus a proper selection of patient and device is required. Close monitoring and facilities for emergency surgical management should be available for all patients while an experienced operator deploys the device across the interatrial communication. Use of the devices is currently indicated in patients who have small defects with a patent foramen ovale and paradoxic embolism, interatrial communications after a fenestrated Fontan operation, and in children and adults who cannot undergo a surgical procedure. Use of these devices may buy time in some and may avoid surgery altogether in others.

Contributions to patient care by the staff of the Departments of Cardiovascular and Thoracic Surgery, Cardiology, and Anesthesiology and by Professor Das are acknowledged.

\section{REFERENCES}

1. King TD, Thomopson SL, Steiner C, Mills NL. Secundum atrial septal defect: nonoperative closure during cardiac catheterization. JAMA 1976;235:2506-9.

2. Das GS, Voss G, Jarvis G, Wyche K, Gunther R, Wilson RF. Experimental atrial septal defect closure with a new transcatheter, self-centering device. Circulation 1993;88(Suppl): I1754-64.

3. Dickinson DF, Arnold R, Wilkinson JL. Congenital heart disease among 160,480 live born children in Liverpool 1960 to 1969: implications for surgical management. Br Heart J 1981;46:56-62.

4. Hagen PT, Scholz DG, Edwards WG. Incidence and size of patent foramen ovale during the first 10 decades of life: an autopsy study of 965 normal hearts. Mayo Clin Proc 1984;59: $17-20$.

5. de Belder MA, Tourikis L, Leech G, Camm JA. Risk of patent foramen ovale for thromboembolic events in all age groups. Am J Cardiol 1992;69:1316-20.

6. Lock JE, Rome JJ, Davis R, et al. Transcatheter closure of atrial septal defects: experimental studies. Circulation 1989; 79:1091-9.

7. Sideris EB, Sideris RN, Fowlkes JP, Ehly RL, Smith JE, Gulde RE. Transvenous atrial septal defect occlusion in piglets with a "buttoned" double-disk device. Circulation 1990;81:312-8.
8. Rashkind WJ. Transcatheter treatment of congenital heart disease. Circulation 1983;67:711-6.

9. Beekman RH, Rocchini AP, Snider AR, Rosenthal A. Transcatheter atrial septal defect closure: preliminary experience with the Rashkind occluder device. J Intervent Cardiol 1989;2:35-41.

10. Redingtion AN, Rigby ML. Transcatheter closure of interatrial communications with a modified umbrella device. $\mathrm{Br}$ Heart J 1994;72:372-7.

11. Rome JJ, Keane JF, Perry SB, Spevak PJ, Lock JE. Double umbrella closure of atrial defects: initial clinical applications. Circulation 1990;82:751-8.

12. Latson LA, Benson LN, Hellenbrand WE, Mullins CE, Lock JE. Transcatheter closure of ASD: early results of multicenter trial of Bard clamshell septal occluder (abstract). Circulation 1991;84(Suppl) II544.

13. Bridges ND, Hellenbrand WE, Latson L, Filiano J, Newburger JW, Lock JE. Transcatheter closure of patent foramen ovale after presumed paradoxical embolism. Circulation 1992;86:1902-8.

14. Prewitt KC, Gaither NS, Farb A, Wortham DC. Transient ischemic attacks after long-term clamshell occluder implantation for closure of atrial septal defect. Am Heart $\mathbf{J}$ 1992; 124:1394-7.

15. Ruiz CE, Gamra H, Mahrer P, Allen JW, O'Laughlin MP, Lan FYK. Percutaneous closure of a secundum atrial septal defect and double balloon valvotomies of a severe mitral and aortic valve stenosis in a patient with Lutembacher's syndrome and severe pulmonary hypertension. Cathet Cardiovasc Diagn 1992;25:309-12.

16. O'Laughlin MP, Bricker JT, Mullins CE, Cabalka AK, Gelb $\mathrm{BD}$, Towbin JA. Transcatheter closure of residual atrial septal defect following cardiac transplantation. Cathet Cardiovasc Diagn 1993;28:162-3.

17. Rosenfeld HM, Vander Velde ME, Sanders SP, et al. Echocardiographic predictors of candidacy of successful transcatheter atrial septal defect closure. Cathet Cardiovasc Diagn 1995;34:29-34.

18. Walsh KP, Abrams SE, A device for all lesions: the button ocluder (abstract). Br Heart J 1994;71(Suppl):43.

19. Rao PS, Sideris EB, Hausdort G, et al. International experience with secundum atrial septal defect occlusion by the buttoned device. Am Heart J 1994;128:1022-35.

20. Gutti RS, Dronamraju D, Saha A. Operative findings in failed button device closure of ASD (letter). Ann Thorac Surg 1995;59:793-4.

21. Lloyd TR, Beekman RH. Transcatheter closure of atrial septal defect and patent ductus arteriosus. In: Topol EJ, editor. Textbook of interventional cardiology. 2nd ed. Philadelphia: WB Saunders, 1994:1298-311.

22. Arabia FA, Rosado J, Lloyd TR, Sethi GK. Management of complications of Sideris transcatheter devices for atrial septal defect closure. J Thorac Cardiovasc Surg 1993;106:886-8. 